\title{
Editorial
}

\section{How universities win gold in the Muttleyfication of learning}

David R. Thompson, RN, PhD, FRCN, FAAN

Professor of Nursing

School of Nursing and Midwifery

Queen's University Belfast

Belfast, UK

Roger Watson, RN, PhD, FRCN, FAAN

Professor of Nursing

Faculty of Health Sciences

University of Hull

Hull, UK

Philip Darbyshire, RN, PhD

Director, Philip Darbyshire Consulting Ltd

Adelaide, Australia

Correspondence to David Thompson

E-mail: david.thompson@qub.ac.uk

(C) 2018. This manuscript version is made available under the CC-BY-NC-ND 4.0 license http:// creativecommons.org/licenses/by-nc-nd/4.0/ 
Universities and nursing faculties are changing dramatically, and not always for the better. Rather than serving as bastions of knowledge generation, curation and dissemination they have become corporatized monoliths, engineered to produce commoditized 'outputs' that are 'work ready' and can contribute to the 'knowledge economy'. Rather than their original intended purpose of producing knowledge for its own sake, the focus of universities is on producing measurable, value-for-money entities: the mythical 'work-ready' graduates and if they can 'win' a few gold medals in the process that can be trumpeted by their 'Comms Departments', then so much the better.

The traditional ideals, values and mission of the university have become suffocated by bureaucracy, stifled by command and control and debased by the worst excesses of neoliberalism. Cohesive collegiality has been swamped by creeping corporatization and managerialism (Thompson \& Clark, 2018). As universities have grown in size and complexity, so has the influence and extent of managerialist mindsets, invariably in the quest for that sacred cow 'more bang for buck'. Universities are now being crushed by greater external pressures, top-down decision and policy-making and the seemingly endless measurement and regulation of daily work (Alvesson \& Spicer, 2016).

Taking only one example, note how universities have been falling over each other in order to 'win' a gold medal in the latest TEF (Teaching Excellence Framework). (https://theconversation.com/tef-everything-you-need-to-know-about-the-new-universityrankings-79932) Leave aside the teeth-grindingly awful title that only a university 'Comms/Marketing Department' could love (be assured that the 'Gold medal winning teaching excellence HERE' headlines are already written) and we see that this further exercise in the 'Muttleyfication' (https://www.youtube.com/watch?v=8qkSe4YM7EY) of 
universities has helped institutionalise some of the most blatant bureaucratic nonsense that universities should be challenging and critiquing rather than embracing and mandating. In a recent tweetchat, one of us (PD) found established UK and international universities where faculty are being ordered to read and respond to student 'happy sheet' course evaluations "before the next exam dates" AND then to detail "the course changes that they will make" based on these 'evaluation comments'. You have to rub your eyes reading this. These are universities, supposed bastions of knowledge, research and critique where faculty are being TOLD to privilege and act upon one section of one group's anecdote and opinion over anything remotely resembling evidence. Apparently in a climate of TEF terror and 'attract full-fee-paying students at any cost', all staff resistance is futile.

How much further can the infantilisation of Higher Education go? A good question and the answer may be 'a gweat big dwop'. Not content with the reification of student 'satisfaction' happy sheets and the increasing fragmentation of academic content into eversimpler 'fun-sized' chunks, the faculty that dutifully transformed themselves into 'docile bodies' spouting more and more 'qualispeak' (Darbyshire, 2008) now face the increasing imposition of more and more "mandatory training".

This fresh hell has seen a proliferation of Mandatory Trainings that make cell division look static. No-one would complain that basic fire training was a waste of time. In any university or hospital, we have to know how to get ourselves, colleagues and/or patients safely out of the building and away from danger. Fast forward to today's bureaucracies where 'Mandatory Training' has become a panacea for all current ills and possibly even those that are yet to be discovered. 
We do not believe that these concerns are overstated. A cursory look through some UK university websites found institutions where around 40 "mandatory trainings" are listed for various university staff. One even warned that, "This list is for reference only and, given the current growth in regulation, (our italics) may not be up to date or comprehensive for all staff categories".

http://www.exeter.ac.uk/media/universityofexeter/humanresources/documents/learningd evelopment/Mandatory training Web List.pdf

In other words, this is going to get worse; this may be only the 'thin edge of the wedge'. There are already plenty of rent-seeking professionals out there desperate to have their pet-project become 'mandatory' for health or university staff and students. A glance at the literature shows calls to make the following 'trainings' mandatory: evidence based medicine (Bergold et al., 2005), advocacy (Bhate \& Loh, 2015), communication skills (Bourguin et al., 2014), domestic violence screening (Oehme \& Stern, 2014), airway management (Rewers \& Ostergaard, 2017), 'Faculty Harassment' (https://campuspreventionnetwork.com/blog/three-reasons-faculty-training-mandatoryplus-one-theory/) etc. We could go on...

Such calls have more than good intentions behind them. When $\mathrm{X}$ training, skills or attitudes become mandated for staff or students, then $\mathrm{X}$ needs 'specially trained' staff to teach it, such is its vital importance. Even more specialist trainers must then themselves train such staff to certifiable levels. To 'maintain standards', such trainers must of course undergo special accredited courses (preferably at universities) that need special accreditors to accredit them. Even better if some kind of paid 'award' or pyramid gong can be offered that will keep these organisations and people on the hook (Anyone for an Athena Swan 
medal or a Six Sigma 'black belt'?) You can see where this is going and can probably hear the cash registers ringing. For every nascent 'mandatory training' that is claimed to be essential, there will already be a queue of 'training companies' out there, just waiting to sell the requisite online programme and 'required certification' to any university who can then claim to have 'fulfilled their duty of care', ie they have guarded their corporate ass, shifted the burden of any responsibility firmly on to staff members and ticked yet another compliance box.

Witness the justified furore over the recent revelation that a consulting company was being paid handsomely and engaged widely to provide 'Empowering Women' courses in UK universities with something of a focus on image management and the career benefits of a good designer handbag. https://www.timeshighereducation.com/news/femaleacademics-told-image-more-important-quality-work As professorial men who have never been ordered to attended a 'manbag workshop' in our careers, we empathise with the justified anger of our female research and professorial colleagues at being subjected to such pap in the name of 'empowerment'. We can only imagine the reaction of a Marie Curie or a Rosalind Franklin to suggestions that their research standing could be improved and that they could be taken 'more seriously' if only they devoted more time to their wardrobe and accessories. We can also only speculate as to how many university Athena Swan medal applications cite the provision of this course as 'evidence' of their commitment to gender equity training in the academy.

If you think we may be overstating our case against the metastases of mandatory trainings, there are already courses out there promising to 'certify accreditors' (https://www.accreditedcertifiers.com.au/accredited-certifiers/becoming-a-certifier) and 
for further evidence, consider nursing's existing empire of mentors, preceptors, trainers, accreditors and signers-off that must be involved almost before a nurse or faculty member can even speak with a student. Whatever you do here. Do NOT mention the phrase 'costbenefit analysis'.

Instead of leaders asking and listening to the really important questions, we are often faced with micromanagers, intent on exerting command and control, who can rarely ask beyond "has that been done yet". Mandatory training is almost devoid of any true scholarship or learning: critical thinking, reflection, debate, imagination, curiosity or creativity, replaced inevitably by the latest online mindless box ticking exercise. There is little if any room for meaningful dialogue, discussion or dissent. Rather, there is a set of "right answers" and the faculty job is to comply by keying them in parrot fashion. You will not receive your online pat on the back and 'Certificate of Completion' until you DO key in all the right answers.

To see an equally awful alternative, check out the Home Office's latest "Prevent" training: https://www.elearning.prevent.homeoffice.gov.uk Sit and click literally any random answer box to progress. While a video is playing, go and make a cup of tea, it won't matter. At the end, select the boxes saying that you have 'No understanding' at all', you will be still be able to print out a certificate testifying that you have "Completed the Prevent elearning training course'. It is THAT meaningless. As UK Universities now have a 'Prevent Duty', thanks to another government needing an 'announcable', they will be proclaiming how seriously they take their 'Prevent Responsibilities' and how committed they are to safeguarding and 'providing support' for anyone deemed 'vulnerable'. Part of this will of course be mandatory staff training and to help, the government has produced a 40 page 
'training catalogue'. There will be plenty of content there that can made mandatory for staff, thus demonstrating your institution's 'full commitment' to the cause.

The reason why such an educational nadir exists is that mandatory trainings have nothing at all to do with learning. They have instead, everything to do with compliance and protecting the university from any charge or suggestion that they may have 'failed in some perceived duty'. It matters not a whit that staff learn, think, change behaviour or whatever. It matters ONLY that the correct percentage of staff have 'undertaken' the said training. If we did this with students' education we would be pilloried and rightly so.

\section{References}

Alvesson, M., \& Spicer, A. (2016). The stupidity paradox: The power and pitfalls of functional stupidity at work. London: Allen \& Unwin.

Bergold, M., Ginn, T.C., Schulze, J., \& Weberschock, T. (2005). First mandatory training in evidence-based medicine in the Medical Education Programme of the University of Frankfurt. Zeitschrift fur Ärztliche Fortbildung und Qualitätssicherung, 99(7), 431435.

Bhate, T.D., \& Loh, L.C. (2015). Building a generation of physician advocates: the case for including mandatory training in advocacy in Canadian Medical School Curricula'. Academic Medicine, 90(12), 1602-1606. 
Bourquin, C., Stiefel, F., Bernhard, J., Bianchi Micheli, G., Hürny, C., Wössmer, B., \& Kiss, A. (2014). Mandatory communication skills training for oncologists: enforcement does not substantially impact satisfaction. Supportive Care in Cancer, 22910), 2611-2614.

Darbyshire, P. (2008). 'Never mind the quality, feel the width': the nonsense of 'quality', 'excellence', and 'audit' in education, health and research. Collegian, 15(1), 35-41.

Darbyshire, P., \& Thompson, D. R. (2014). How academic nursing is being enriched by the Thriller elite. Journal of Advanced Nursing, 70(10), 2165-2166.

Oehme, K. \& Stern, N. (2014). The case for mandatory training on screening for domestic violence in the wake of the Affordable Care Act'. University of Pennsylvania Journal of Law and Social Change, 17(1), 1-28.

Thompson, D. R., \& Clark, A. M. (2013). Academic culture in nursing: Devalued, defiant or dead? International Journal of Nursing Studies, 50(11), 1431-1433.

Thompson, D. R., \& Clark, A. M. (2018). Leading by gaslight?: Nursing's academic leadership struggles. Journal Advanced Nursing, ; in press

Thompson, D. R., \& Darbyshire, P. (2013). Is academic nursing being sabotaged by its own Killer elite? J Advanced Nursing, 69(1), 1-3.

Thompson, D.R., \& Watson, R. (2001). Academic nursing - what is happening to it and where is it going? Journal of Advanced Nursing, 36(1), 1-2.

Thompson, D. R., \& Watson, R. (2006). Professors of nursing: what do they profess? Nurse Education in Practice, 6(3), 123-126.

Thompson, D. R., \& Watson, R. (2013). Professing nursing or not: what's in a title. Nurse Education Today, 33(8), 765. 
Watson, R., \& Thompson, D. R. (2008). Professors as leaders. Journal of Clinical Nursing, 17(8), 981-982. 